\title{
Kondisi Fisik, Pengetahuan, Pendidikan, Pekerjaan Ibu, dan Lama Pemberian ASI Secara Penuh
}

\author{
Physical Status, Knowledge, Education, Mother's Occupation and Full \\ Breastfeeding Duration
}

\author{
Muhammad Tahir Abdullah, Alimin Maidin, Andi Dwi Lestari Amalia
}

\section{Bagian Biostatistik Fakultas Kesehatan Masyarakat Universitas Hasanuddin}

\begin{abstract}
Abstrak
Berbagai studi dan pengamatan memperlihatkan kecenderungan penurunan pemberian ASI dan berganti dengan susu fomula menjadi kebiasaan umum di dalam masyarakat. Penelitian ini bertujuan mengetahui pola pemberian ASI pada periode 12 bulan umur bayi dan perbedaan pengaruh variabel determinan terhadap lama pemberian ASI secara penuh ( $A S I$ secara penuh) tanpa makanan lain. Penelitian observasional analitik yang dilaksanakan di dua wilayah kerja puskesmas Kecamatan Tallo Kota Makassar ini menggunakan rancangan studi potong lintang dengan jumlah sampel 300 responden. Analisis multivariat dilakukan dengan metode Cox Proportional Hazard. Hasil penelitian menunjukkan bahwa proporsi bayi untuk mendapatkan ASI secara penuh pada bulan pertama adalah sekitar 0,86 , pada bulan ke 6 menurun sekitar $31 \%$, dan pada periode 5,06 bulan menurun menjadi sekitar $50 \%$. Ada perbedaan lama pemberian ASI secara penuh berdasarkan variabel keadaan fisik ibu, pengetahuan ibu, pendidikan, dan pekerjaan. Hasil analisis lanjut menunjukkan variabel yang berbeda secara nyata dalam hubungan dengan durasi pemberian ASI secara penuh adalah keadaan fisik ibu dan pengetahuan ibu.

Kata kunci : ASI secara penuh, cox proportional hazard, pengetahuan, status fisik
\end{abstract}

\footnotetext{
Abstract

Various studies and observations indicate declining trend of breastfeeding and replacing breast milk with formula is already a common thing in society. This study aimed to find out the pattern of breastfeeding in infants up to 12 months, and to know the difference effect of the determinant variables of full breastfeeding. This observational research with cross sectional study design that involved 300 respondents was conducted in the Tallo District of Makassar City. Data analysis was performed by univariate, bivariate with Kaplan Meier and multivariate with Cox Proportional Hazard. The results showed that proportion of infants get full breastfeeding in first month was 0.86 , infants who still get full breastfeeding on the 6 th month are $31 \%$, and
}

half of the number of infants are not get full breastfeeding after 5.06 months. There are differences in the duration of full breastfeeding on the mother's physical status, education, and occupation. The further analysis showed a markedly different variables in influencing the duration of full breastfeeding are mother's phisical status and knowledge.

Keywords: Full breastfeeding, cox proportional hazard, knowledge, physical status

\section{Pendahuluan}

Air susu ibu (ASI) merupakan makanan alamiah yang ideal untuk bayi, terutama pada bulan-bulan pertama. Pemberian ASI pada bayi bukan saja berarti memberikan awal kehidupan yang sehat dan bergizi, tetapi lebih dari itu merupakan cara yang hangat, penuh kasih dan menyenangkan. Menyusui dianggap sebagai metode yang ideal untuk bayi setidaknya selama enam bulan pertama kehidupan. Berdasarkan penelitian, semakin lama seorang bayi mengonsumsi ASI, semakin sehat kondisi fisik bayi karena ASI mengandung antibodi khusus yang tidak terdapat dalam makanan lain. World Health Organization (WHO) mencanangkan pemberian ASI eksklusif sampai bayi berusia 6 bulan, dan ASI dapat diberikan sampai anak berumur dua tahun.

Penelitian di Turki pada tahun 2007, rata-rata lama menyusui pada bayi usia 1 bulan adalah sekitar 95,3\%, bayi usia 3 bulan sekitar $86,0 \%$, bayi usia 6 bulan seki$\operatorname{tar} 65,7 \%$, bayi usia 12 bulan sebesar $39,0 \%$, bayi usia 18 bulan sebesar $14,3 \%$ dan bayi usia 24 bulan sebesar

Alamat Korespondensi: Muhammad Tahir Abdullah, Bagian Biostatistika FKM Universitas Hasanuddin, Jl. Perintis Kemerdekaan Km. 10 Makassar Sulawesi Selatan 90245, Hp.082196436530,e-mail: mtahirabd@gmail.com 
4,0\%. ${ }^{1}$ Penelitian di Thailand Utara, pada akhir tahun pertama, sekitar $60 \%$ bayi masih disusui, $7 \%$ bayi masih menyusui di usia 24 bulan. Mayoritas bayi (63\%) benarbenar disapih pada kisaran usia 10 dan 15 bulan. $^{2}$ Di Nepal Barat tahun 2005, ibu berhenti menyusui ketika anak berusia 3 tahun sekitar 35,1\%, sekitar 18,7\% ibu berhenti menyusui ketika anak berusia 2,5 tahun dan 18,2\% ketika anak berusia 2 tahun. ${ }^{3}$

Di Indonesia, menurut SDKI, jumlah pemberian ASI eksklusif pada bayi di bawah usia dua bulan hanya mencakup $67 \%$ dari total bayi yang ada. Sekitar 54\% pada bayi usia 2 - 3 bulan dan $19 \%$ pada bayi usia 7 - 9 bulan. Sekitar $13 \%$ bayi berusia di bawah dua bulan telah diberi susu formula dan satu dari tiga bayi usia 2 - 3 bulan telah diberi makanan tambahan. Angka kematian ibu di Sulawesi Selatan pada tahun 2008 mencapai 119/ 100.000 dengan 61,3\% disebabkan perdarahan. Pada tahun 2009, kasus ini menurun dan meningkat kembali pada tahun 2010. ${ }^{4}$ Pada tahun 2006, cakupan pemberian ASI ekslusif di Sulawesi Selatan sekitar 57,48\% pada tahun 2007 sekitar 57,05\%, tahun 2008 sekitar 77,18\%, dan tahun 2009 sekitar 59,80\%. ${ }^{5}$ Penelitian ini bertujuan mengetahui pola pemberian ASI dan perbedaan lama pemberian ASI secara penuh berdasarkan variabel determinan di Kecamatan Tallo, Kota Makassar, yang merupakan praktik belajar lapangan FKM Unhas sejak tahun 2006.

\section{Metode}

Penelitian ini dilakukan di Puskesmas Ujung Pandang Baru dan Puskesmas Kaluku Boddoa Kecamatan Tallo Kota Makassar, pada tanggal 14 Februari - 7 April 2012. Penelitian observasional analitik ini menggunakan rancangan studi potong lintang. Variabel dependen adalah lama pemberian ASI secara penuh, variabel independen adalah kondisi fisik ibu, dukungan suami, pengetahuan ibu, usia ibu, pendidikan ibu, pekerjaan ibu, paritas, dan kesehatan anak. Populasi penelitian adalah semua ibu yang mempunyai anak usia $0-12$ bulan yang berada di wilayah kerja Puskesmas Ujung Pandang Baru dan Puskesmas Kaluku Boddoa di Kecamatan Tallo. Sampel berjumlah $300 \mathrm{ibu}$ yang diambil dengan metode proportional stratified random sampling. Pengumpulan data primer dilakukan dengan wawancara langsung pada responden menggunakan kuesioner di setiap posyandu. Data yang dikumpulkan sesuai dengan data yang dibutuhkan dalam penelitian.

Analisis pola pemberian ASI digunakan metode life table pada analisis survival dan untuk mengetahui lama pemberian ASI secara penuh dilakukan uji Kaplan Meyer sedangkan untuk melihat kemaknaan digunakan tes Logrank. Pada analisis ini dilakukan uji secara bersamasama sehingga dapat dilihat variabel yang paling memengaruhi lama pemberian ASI secara penuh dengan meng- gunakan The Cox Proportional Hazards Model.

\section{Hasil}

Kondisi fisik ibu merupakan keadaan kesehatan ibu selama memberikan ASI dan umumnya ibu mempunyai kondisi fisik yang sehat. Dukungan suami merupakan persetujuan dan bantuan pada istri agar anak dapat diberi ASI, dan sebagian besar suami mendukung istri. Pengetahuan ibu adalah ibu mengetahui tentang kebaikan ASI dan menyusui, dan sebagian besar ibu mempunyai pengetahuan cukup. Sebagian besar ibu pada saat diwawancarai berumur diatas 20 tahun. Umumnya ibu mempunyai pendidikan menengah ke atas. Ibu yang menyatakan tidak mempunyai pekerjaan dan harus meninggalkan rumah merupakan yang terbanyak. Kebanyakan responden adalah ibu yang mempunyai satu atau dua anak, dan hampir semua ibu menyatakan anak dalam keadaan sehat selama diberi ASI (Tabel 1).

Proporsi bayi yang mendapatkan ASI secara penuh pada bulan pertama sejak kelahiran adalah $86 \%$, dan mengalami penurunan setiap bulan. Bayi yang tetap mendapat ASI secara penuh sampai bulan ke-6 hanya sekitar $31 \%$. Masuk pada bulan ke-6 dan ke-7 proporsi bayi yang mendapatkan ASI secara penuh menurun tajam yaitu masing-masing $5 \%$ dan $2 \%$. Nilai median 4,06 menunjukkan setengah atau $50 \%$ dari jumlah bayi sudah tidak mendapatkan ASI secara penuh setelah usia empat bulan (Tabel 2).

Variabel status fisik ibu, pengetahuan ibu, pendidikan ibu, dan pekerjaan ibu bernilai signifikansi baik Logrank, Breslow dan Tarone-Ware. Sedangkan variabel dukungan suami, usia ibu, pendidikan ibu, paritas, dan kesehatan anak, lama pemberian ASI secara penuh tidak berbeda. Ibu dengan status fisik sehat memberikan ASI secara

Tabel 1. Distribusi Berdasarkan Kondisi Fisik, Pengetahuan, Pendidikan, dan Pekerjaan Ibu

\begin{tabular}{llll}
\hline Variabel & Kategori & $\mathbf{n}$ & $\%$ \\
\hline Fisik ibu & Sehat & 294 & 98,0 \\
Dukungan suami & Sakit & 6 & 2,0 \\
& Mendukung & 275 & 91,7 \\
Pengetahuan & Tidak mendukung & 25 & 8,3 \\
& Cukup & 188 & 62,7 \\
Usia (tahun) & Kurang & 112 & 37,3 \\
& $<20$ & 34 & 11,3 \\
& $20-35$ & 225 & 75,0 \\
Pendidikan & $>35$ & 41 & 13,7 \\
& Rendah & 88 & 29,3 \\
Pekerjaan & Menengah & 194 & 64,7 \\
& Tinggi & 18 & 6,0 \\
Paritas (n) & Bekerja & 33 & 11,0 \\
& Tidak bekerja & 267 & 89,0 \\
& $\leq 2$ & 186 & 62,0 \\
Kesehatan anak & $3-4$ & 81 & 27,0 \\
& $\geq 5$ & 33 & 11,0 \\
& Sehat & 299 & 99,7 \\
& Sakit & 1 & 0,3 \\
\hline
\end{tabular}


Tabel 2. Pola Pemberian ASI

\begin{tabular}{cccccc}
\hline $\begin{array}{c}\text { Waktu Mulai } \\
\text { Interval }\end{array}$ & $\begin{array}{c}\text { Jumlah Memasuki } \\
\text { Interval }\end{array}$ & $\begin{array}{c}\text { Jumlah Kejadian } \\
\text { Terminal }\end{array}$ & $\begin{array}{c}\text { Proporsi } \\
\text { Mengakhiri }\end{array}$ & $\begin{array}{c}\text { Proporsi } \\
\text { Ketahanan }\end{array}$ & $\begin{array}{c}\text { Proporsi Kumulatif } \\
\text { Ketahanan 1 }\end{array}$ \\
\hline 0 & 300 & 53 & 0,18 & 0,82 & 0,82 \\
1 & 247 & 35 & 0,14 & 0,86 & 0,71 \\
2 & 212 & 21 & 0,10 & 0,90 & 0,64 \\
3 & 191 & 39 & 0,20 & 0,80 & 0,51 \\
4 & 152 & 32 & 0,21 & 0,79 & 0,40 \\
5 & 120 & 26 & 0,22 & 0,78 & 0,31 \\
6 & 94 & 80 & 0,85 & 0,15 & 0,05 \\
7 & 14 & 8 & 0,57 & 0,43 & 0,02 \\
9 & 6 & 5 & 0,83 & 0,17 & 0,00 \\
10 & 1 & 0 & 0,00 & 1,00 & 0,00 \\
\end{tabular}

Tabel 3. Distribusi Frekuensi Variabel Independen

\begin{tabular}{|c|c|c|c|c|c|}
\hline \multirow{2}{*}{ Variabel } & \multirow{2}{*}{ Kategori } & \multirow{2}{*}{ Lama Pemberian ASI Secara Penuh } & \multicolumn{3}{|c|}{ Uji (p) } \\
\hline & & & Logrank & Breslow & Tarone-ware \\
\hline \multirow[t]{2}{*}{ Fisik ibu } & Sehat & 4,271 & 0,000 & 0,000 & 0,000 \\
\hline & Sakit & 0,833 & & & \\
\hline \multirow[t]{2}{*}{ Dukungan suami } & Mendukung & 4,187 & 0,889 & 0,522 & 0,727 \\
\hline & Tidak mendukung & 4,480 & & & \\
\hline \multirow[t]{2}{*}{ Pengetahuan } & Cukup & 4,391 & 0,007 & 0,021 & 0,007 \\
\hline & Kurang & 3,955 & & & \\
\hline \multirow[t]{3}{*}{ Usia (tahun) } & $<20$ & 4,068 & 0,805 & 0,926 & 0,925 \\
\hline & $20-35$ & 4,261 & & & \\
\hline & $>35$ & 3,834 & & & \\
\hline \multirow[t]{3}{*}{ Pendidikan } & Rendah & 4,639 & 0,047 & 0,036 & 0,034 \\
\hline & Menengah & 4,095 & & & \\
\hline & Tinggi & 3,326 & & & \\
\hline \multirow[t]{2}{*}{ Pekerjaan } & Bekerja & 3,364 & 0,031 & 0,042 & 0,047 \\
\hline & Tidak bekerja & 4,315 & & & \\
\hline \multirow[t]{3}{*}{ Paritas (n) } & $\leq 2$ & 4,205 & 0,768 & 0,579 & 0,807 \\
\hline & $3-4$ & 4,245 & & & \\
\hline & $\geq 5$ & 3,823 & 0,496 & 0,851 & 0,674 \\
\hline \multirow[t]{2}{*}{ Kesehatan anak } & Sehat & 4,203 & & & \\
\hline & Sakit & 4,000 & & & \\
\hline
\end{tabular}

penuh lebih lama $(4,27$ bulan) daripada status fisik ibu yang sakit. Pengetahuan ibu yang cukup memberikan ASI secara penuh lebih lama (4,39 bulan) daripada ibu yang berpengetahuan kurang. Pendidikan ibu yang rendah memberikan ASI secara penuh lebih lama $(4,64$ bulan) daripada ibu yang berpendidikan tinggi. Ibu yang tidak bekerja memberikan ASI secara penuh lebih lama (4,32 bulan) daripada ibu yang bekerja (Tabel 3).

Berdasarkan hasil analisis multivariat, terdapat perbedaan yang signifikan lama pemberian ASI secara penuh pada ibu berdasarkan kondisi fisik ibu dan pengetahuan ibu setelah variabel independen yang lain diperhitungkan. Kondisi fisik ibu lebih dominan dibanding dengan pengetahuan ibu. Variabel pendidikan ibu dan pekerjaan ibu tidak lagi berhubungan bermakna dengan lama pemberian ASI secara penuh (Tabel 4).

\section{Pembahasan}

Perbedaan yang nyata ditemukan dalam pemberian
ASI secara penuh berdasarkan kondisi fisik ibu, pengetahuan ibu, pendidikan, dan pekerjaan ibu dalam analisis bivariat. Kondisi fisik ibu sangat memengaruhi jumlah produksi ASI, terutama ibu yang mempunyai penyakit yang menyebabkan ibu tidak dapat menyusui. Hal ini dapat berdampak terhadap lama menyusui. Alasan ibu yang sering untuk tidak menyusui adalah karena ibu sakit, sebentar atau lama. Akan tetapi, jarang sekali ada penyakit yang mengharuskan berhenti menyusui, kecuali jika ibu mengonsumsi obat yang dapat memengaruhi produksi ASI.

Sebagian besar ibu dengan kondisi fisik yang sakit berhenti memberikan ASI secara penuh pada bayi dengan alasan ASI sedikit atau sama sekali tidak keluar atau karena merasa kesakitan akibat penyakit yang diderita oleh ibu. Hasil penelitian ini sesuai dengan penelitian di Vietnam. Kesehatan ibu dapat memengaruhi keputusan menyusui terutama bagi yang melakukan operasi caesar, ada peningkatan untuk tidak menyusui 
Tabel 4. Analisis Multivariat Cox Proportional Hazard Lama Pemberian ASI Secara Penuh

\begin{tabular}{llcccc}
\hline Variabel & B & SE & Nilai p & OR & 95\% CI \\
\hline Fisik & $-1,571$ & 0,443 & 0.000 & 0,208 & $0,087-0,495$ \\
Dukungan suami & 0,073 & 0,240 & 0,760 & 1,076 & $0,673-1,721$ \\
Pengetahuan & $-0,354$ & 0,148 & 0,017 & 0,702 & $0,526-0,938$ \\
Usia ibu (tahun) & & & 0,952 & & \\
$\quad<20$ & 0,088 & 0,333 & 0,790 & 0,915 & $0,477-1,757$ \\
$\quad 20-35$ & 0,067 & 0,224 & 0,763 & 0,935 & $0,603-1,449$ \\
Pekerjaan & 0,319 & 0,245 & 0,192 & 1,376 & $0,852-2,223$ \\
Paritas (n) & & & 0,916 & & \\
$\quad 1-2$ & $-0,078$ & 0,242 & 0,746 & 0,925 & $0,575-1,487$ \\
$\quad$ 3-4 & $-0,015$ & 0,241 & 0,950 & 0,985 & $0,615-1,579$ \\
Pendidikan & & & 0,648 & & \\
$\quad$ Rendah & $-0,203$ & 0,346 & 0,556 & 0,816 & $0,414-1,607$ \\
$\quad$ Tinggi & $-0,055$ & 0,320 & 0,864 & 0,947 & $0,505-1,773$ \\
$\quad$ Sehat & $-0,861$ & 1,033 & 0,405 & 0,423 & $0,056-3,203$ \\
\hline
\end{tabular}

secara eksklusif. ${ }^{6}$ Pengetahuan dan sikap terhadap kesehatan merupakan salah satu faktor predisposisi yang memengaruhi perilaku. Jika seorang ibu hamil tidak pernah mendapatkan informasi atau penyuluhan mengenai pemberian ASI eksklusif, dapat berpengaruh dalam pemberian ASI ekslusif pada bayi di kemudian hari. ${ }^{7}$

Banyak ibu dengan pengetahuan yang cukup cenderung memberikan ASI secara penuh lebih lama jika daripada ibu yang mempunyai pengetahuan yang kurang. Banyak faktor yang memengaruhi keputusan ibu dalam lama pemberian ASI secara penuh kepada bayi. Rata-rata ibu dengan pengetahuan cukup memperoleh informasi dari kegiatan penyuluhan dan konsultasi tentang menyusui bidan dan kader posyandu. Pengetahuan yang cukup tentang menyusui bayi yang penting dapat mendorong ibu untuk memberikan ASI secara penuh. Di Ankara, Turki, konseling menyusui penting selama beberapa bulan pertama sangat diperlukan untuk mencapai sukses menyusui jangka panjang seperti yang diinginkan. ${ }^{1}$

Dilihat dari tingkat pendidikan, seharusnya ibu dengan tingkat pendidikan tinggi mempunyai pengetahuan yang cukup tentang memberikan ASI kepada bayi daripada ibu dengan tingkat pendidikan rendah dan menengah. ${ }^{8}$ Ternyata kelompok ibu dengan tingkat pendidikan rendah dan pendidikan menengah cenderung untuk memberikan ASI lebih lama daripada kelompok ibu yang mempunyai tingkat pendidikan tinggi karena rata-rata ibu yang mempunyai tingkat pendidikan tinggi mempunyai pekerjaan sehingga proporsi untuk memberikan ASI menjadi berkurang.

Proporsi ibu yang pendidikan tinggi yang menyusui lebih rendah daripada ibu dengan pendidikan yang lebih rendah. Penelitian di beberapa negara menunjukkan bahwa ibu yang bekerja di luar rumah merupakan salah satu faktor penyebab penurunan proporsi menyusui tersebut. Di banyak negara berkembang, tenaga kerja perempuan yang melahirkan anak setiap tahun meningkat pesat, menjadi tantangan baru bagi perempuan yang mencoba menggabungkan peran mereka sebagai pekerja dan ibu. Rata-rata ibu yang bekerja tetap memberikan susu formula kepada bayi karena anak ditinggal di rumah ketika ibu pergi, susu formula diberikan sebagai pengganti ASI hingga ibu pulang ke rumah. Ada pula ibu yang tidak bekerja memberikan susu formula kepada anak karena merasa anak tidak kenyang jika hanya diberikan ASI. Pola pikir ini juga dipengaruhi oleh faktor pengetahuan ibu tentang menyusui. Di Pekalongan dan Nairobi, perkembangan perilaku ibu dalam pemberian ASI mengalami pergeseran pada golongan ibu pekerja. Proporsi pemberian ASI cenderung menurun. ${ }^{9,10}$

\section{Kesimpulan}

Proporsi bayi untuk mendapatkan ASI secara penuh pada bulan pertama adalah $86 \%$, dan menjelang usia enam bulan, proporsi ASI secara penuh hanya $31 \%$, dan masih jauh dari target nasional $(80 \%)$. Sementara, bayi yang tetap mendapatkan ASI secara penuh pada bulan ke-7 menurun tajam sekitar 2\%, serta nilai median tidak lagi mendapatkan ASI secara penuh setelah usia 4,06 bulan. Ada perbedaan lama pemberian ASI secara penuh berdasarkan kondisi fisik ibu, pengetahuan.

\section{Saran}

Pengetahuan masyarakat tentang kepentingan menyusui perlu ditingkatkan sehingga dapat menimbulkan kesadaran dalam pemberian ASI secara penuh lebih lama. Kesadaran keluarga, terutama suami juga perlu ditingkatkan agar senantiasa memberikan dukungan kepada ibu agar terus memberikan ASI secara penuh kepada anaknya. Informasi tentang cara menjaga kelangsungan pemberian ASI secara penuh dilakukan terutama pada ibu yang bekerja. Peranan petugas kesehatan dalam memberikan penyuluhan dan konsultasi tentang penting 
pemberian ASI secara penuh kepada ibu dan suami serta seluruh anggota masyarakat perlu ditingkatkan sehingga pengetahuan ibu, keluarga, dan masyarakat semakin meningkat.

\section{Daftar Pustaka}

1. Camurdan A, Mustafa IN, Ufuk B, Figen S, Nilgun V, Sancar E. How to achieve long-term breastfeeding: factors associated with early discontinuation. Public Health Nutrition. 2007; 11 (11): 1173-9.

2. Jackson DA, Imong SM, Wongsawasdii L, Silprasert A, Preulangpoo S, Leelapat $\mathrm{P}$, et al. Weaning practices and breastfeeding duration in Northern Thailand. British Journal of Nutrition. 1990; 61: 149-64

3. Chandrashekhar TS, Joshi HS, Binu VS, Shankar PR, Rana MS, Rachmandran U. Breastfeeding initiation and determinants of exclusive breastfeeding - a questionnaire survey in an urban population of Western Nepal. Public Health Nutrition. 2005; 10(2): 192-7.

4. Dinas Kesehatan Provinsi Sulawesi Selatan. Profil dinas kesehatan Provinsi Sulawesi Selatan tahun 2010. Makassar: Dinas Kesehatan
Provinsi Sulawesi Selatan; 2010.

5. Sudarianto. Dilaporkan sebanyak 210 balita mati atau 1,40 per 1000 KH [online]. 2010 [diakses tanggal 12 Oktober 2011]. Diunduh dalam: www.litbang.depkes.go.id.

6. Duong V, Colin Binns W, Andy Lee H. Breastfeeding initiation and exclusive breastfeeding in rural Vietnam. Public Health Nutrition. 2003; 7 (6): 795-9.

7. Eka M. Faktor-faktor yang mempengaruhi lama pemberian ASI eksklusif [Tesis]. Depok: Universitas Indonesia; 2009.

8. Al-Akour AN, Khassawneh MY, Khader YS, Ababneh AA, Haddad AM. Factors affecting intention to breastfeed among Syrian and Jordanian mothers: a comparative cross-sectional study. International Breast feeding Journal. 2010; 5: 6 .

9. Falah N. Beberapa faktor yang mempengaruhi lamanya pemberian air susu ibu pada ibu bekerja bagian produksi di PT. Pisma Putra Tekstil Pekalongan [Tesis]. Semarang: Universitas Diponegoro; 2004.

10. Lakati A, Binns C, Stevenson M. Breast-feeding and the working mother in Nairobi. Public Health Nutrition. 2001; 5 (6): 715-8. 